and use as a fluorescence probe of lipid. Biochemistry 20:7333-7338

29. Blatt E, Sawyer WH 1985 Depth-dependent fluorescent quenching in micelles and membranes. Biochim Biophys Acta 822:43-62

30. Thulborn KR 1981 The use of $n$-(9-anthroyloxy) fatty acids as fluorescent probes for biomembranes. In: Beddard GS, West MA (eds) Fluorescent Probes. Academic Press, London, pp 113-139

31. Inbar M, Goldman R, Inbar L, Bursuker I, Goldman B, Akstein E, Segal P, Ipp E, Ben-Bassat I 1977 Fluidity differences of membrane lipids in human normal and leukemic lymphocytes as controlled by serum components. Cancer Res 37:3037-3041

32. Fisher RA 1954 Statistical Methods for Research Workers. Edinburgh, pp $197-$ 204

33. Barenholz Y 1984 Sphingomyelin-lecithin balance in membranes: composition, structure, and function relationships. In: Shinitzky M (ed) Physiology of Membrane Fluidity, vol I. CRC Press, Boca Raton, FL, pp 131-173

34. Hoover RL, Dawidowicz EA, Robinson JM, Karnovsky MJ 1983 Role of cholesterol in the capping of surface immunoglobulin receptors on murine lymphocytes. J Cell Biol 97:73-80

35. Ben-Bassat H, Polliak A, Rosenbaum SM, Naparstek E, Shouval D, Inbar M 1977 Fluidity of membrane lipids and lateral mobility of concanavalin A receptors in the cell surface of normal lymphocytes and lymphocytes from patients with malignant lymphomas and leukemias. Cancer Res 37:13071312

36. Jackson MJ, Wagenmakers AJM, Edwards RHT 1987 Effect of inhibitors of arachidonic acid metabolism on efflux of intracellular enzymes from skeletal muscle following experimental damage. Biochem J 241:403-407

37. Hunter MIS, Mohamed JB 1986 Plasma antioxidants and lipid peroxidation products in Duchenne muscular dystrophy. Clin Chim Acta 155:123-131

\title{
Announcements
}

\author{
Abstract Deadline
}

The American Pediatric Society and the Society for Pediatric Research announce the abstract deadline for the 1988 Annual Meeting (May 2-6, Washington Sheraton Hotel, Washington, D.C.) has been set as December 10, 1987. For further information contact: SPR-Debbie L. Wogenrich, The Society for Pediatric Research, 2350 Alamo S.E., Suite 106, Albuquerque, NM 87106 (505)764-9099. APS-Dr. Audrey K. Brown, Secretary-Treasurer, Department of Pediatrics, Box 49, SUNY, Health Sciences Center at Brooklyn, 450 Clarkson Avenue, Brooklyn, NY 11203, (718)270-1692.

\section{Mechanisms and Management of Pediatric Hepatobiliary Disease}

The conference will be held on February 28-March 1, 1988 at the Hyatt Regency Crystal City at Washington National Airport, 2799 Jefferson Davis Highway, Arlington, VA. The Conference is sponsored by the National Digestive Diseases Advisory Board, National Institute of Diabetes and Digestive and Kidney Diseases, National Institute of Child Health and Human Development, and the American Liver Foundation.

The program is disigned for basic and clinical investigators and physicians in practice. The registration fee of $\$ 50.00$ includes participation in all plenary and workshop sessions and three working lunches during the conference. To receive registration materials, please send name, title, affiliation, mailing address, and telephone number to Ms. Marti Bernstein, Prospect Associates, Suite 500, 1801 Rockville Pike, Rockville, MD 20852 or call the Conference Registrar at (301) 468-MEET. Limited travel funds may become available for young investigators. Those wishing to be considered should submit a letter of application to Ms. Bernstein, including reasons for wanting to attend the conference, its relevance to your work, a brief $\mathrm{CV}$, and a letter from your preceptor or a senior associate. Applications for travel assistance must be received by December 1, 1987. 